\title{
Kemampuan Berpikir Tingkat Tinggi Dalam Menyelesaikan Soal HOTS Mata Pelajaran Matematika
}

\author{
*Putu Manik Sugiari Saraswati ${ }^{1}$, Gusti Ngurah Sastra Agustika ${ }^{2}$ \\ ${ }^{1,2,}$ Prodi Pendidikan Guru Sekolah Dasar, Universitas Pendidikan Ganesha
}

\section{A R T I C L E I N F O}

Article history:

25 December 2019

Received in revised form

01 January 2020

Accepted 25 January 2020

Available online 28

February 2020

\section{Kata Kunci:}

soal hots,

kendala pemmecahan

masalah

Key Word:

HOTS tes

obstacles in solving

problems

\begin{abstract}
A B S T R A K
Pesatnya perkembangan pengetahuan dan teknologi abad 21, menuntut manusia memiliki kemampuan berpikir tingkat tinggi. Pada dunia pendidikan, HOTS merupakan kemampuan berpikir siswa yang tidak hanya mengingat tetapi juga diharapkan untuk dapat mengembangkan ide. Penelitian deksriptif ini bertujuan untuk mengetahui kemampuan berpikir tingkat tinggi dan mengetahui kendala dalam menyelesaikan soal HOTS mata pelajaran matematika siswa kelas $V$. Data tersebut dikumpulkan dengan memberikan tes uraian dan wawancara kepada 85 siswa. Hasil analisis PAP pada skor akhir tes menunjukkan seabanyak 45 siswa (53\%) memiliki Kemampuan Berpikir HOTS Cukup. Bagian selanjutnya melalui analisis isi, hasil wawancara menunjukkan terdapat 53 siswa (62\%) siswa mengalami kendala pada proses membuat/membentuk kalimat matematika. Bersumber pada hal tersebut dapat disimpulkan siswa kelas V SDN 1 Padang Sambian cenderung memiliki kemampuan berpikir HOTS cukup serta masih rendah dalam menajawab soal dengan ranah kognitif $\mathrm{C} 6$, sedangkan kendala siswa terdapat pada proses membuat/membentuk kalimat
\end{abstract} matematika. Simpulan yang diperoleh berimplikasi pada peningkatan kemampuan berpikir siswa tiap tingkat ranah kognitif melalui penilaian berbasis HOTS.

\section{A B S T R A C T}

The fast development of knowledge and technology on the $21^{\text {st }}$ century required humans to have highlevel thinking skills. In the world of education, HOTS is the students' thinking ability who do not only remember but also expected to be able to develop the ideas. This descriptive research aims to determine the ability to think at a higher level and to find out the obstacles in solving HOTS questions in mathematics on fifth grade students. The data was collected by giving a description test and interview to 85 students. The results of the PAP analysis on the final score of the test showed that 45 students (53\%) had HOTS Thinking Ability was in the sufficient category. The next part through content analysis, the interview results showed that there were 53 students (62\%) students had problems in the process of forming mathematic sentences. Based on this research, it could be concluded that the fifth grade students of SDN 1 Padang Sambian tend to have sufficient HOTS thinking ability and were still low in answering questions with C6 cognitive domains, while the students' constraints were in the process of forming mathematic sentences. The conclusion obtained had implications in improving students' thinking abilities at each cognitive level through HOTS based assessment..

\section{Pendahuluan}

Sumber Daya Manusia (SDM) pada abad 21 dituntut memiliki 3 kemampuan penting diantaranya, kemampuan berpikir kritis, berpikir kreatif dan memecahkan masalah (Pratiwi,2019:128). Tiga kemampuan tersebut dikenal dengan kemampuan berpikir tingkat tinggi atau HOTS (Higher Order

Corresponding author

Copyright @ Universitas Pendidikan Ganesha. All rights reserved

E-mail addresses: saraswati.manik@gmail.com (Putu Manik Sugiari Saraswati1), gn.sastra.a@undiksha.ac.id (Gusti Ngurah Sastra Agustika2), putra.made3112@gmai.com (Made Putra ${ }^{3}$ ) 
Thinking Skill). Seperti yang diungkapkan oleh Sani (2019:52) bahwa hal penting yang perlu dilakukan ialah mempersiapkan generasi muda dengan bekal kemampuan berpikir kritis, kreatif serta trampil dalam mengambil keputusan guna memecahkan masalah. Sementara itu Faridah (2019:2) juga menyatakan untuk beradaptasi pada abad 21 dibutuhkan kemampuan mengembangkan kreatifitas dan memecahkan masalah. Berpikir kritis dan kreatif dibutuhkan dalam menyelesaikan masalah, sebab pesatnya perkembangan pengetahuan dan teknologi telah menghasilkan tantangan dan masalah yang akan dihadapi manusia di abad 21 menjadi lebih kompleks (Driana dan Ernawti,2019:110). Pesatnya perkembangan pengetahuan dan teknologi pada abad 21 tak serta merta meningkatkan ranking siswa Indonesia pada PISA dan TIMSS. Tercatat pada tahun 2015 Indonesia menduduki peringkat ke-64 dari 72 negara yang berpatisipasi pada PISA, dan menduduki peringkat ke-45 dari 48 negara yang berpatisipasi pada TIMSS (Nugroho, 2018:11). Rendahnya hasil tersebut mengharuskan dunia pendidikan Indonesia mempersiapkan diri untuk menghadapi pesatnya perkembangan pengetahuan dan teknologi abad 21, seperti memperlengkapi siswa dengan HOTS pada pembelajaran.

Sesungguhnya pada dunia pendidikan HOTS mampu diterapkan, sebab kemampuan berpikir tingkat tinggi siswa dapat dilatih dan ditingkatkan. Sehingga banyak negara yang mengunakan HOTS sebagai bagian yang tak terpisahkan dari pembelajaran dikelas (Musrikah, 2018:341). Kemampuan siswa dalam menerima pembelajaran serta cara siswa menyelesaikan masalah pada soal matematika yang berbeda juga membuat mereka memiliki kemampuan berpikir tingkat tinggi yang berbeda pula. Mengingat hakikat manusia diciptakan unik satu sama lain, kemampuan yang dimiliki manusia juga pada dasarnya beragam. Menanggapi hal tersebut Pratiwi (2019:128) menjelaskan untuk mengembangkan item berbasis HOTS yang baik untuk siswa, kualitas guru menjadi bagian yang sangat penting dalam kasus ini. Guru harus memiliki pemahaman yang baik tentang proses kognitif dalam Keterampilan Berpikir Tingkat Rendah (LOTS) dan Keterampilan Berpikir Tingkat Tinggi (HOTS). Terlebih lagi menurut Widana (2017:32) guru memegang peran dalam mengoptimalkan penilaian HOTS, baik dalam tes harian, penilaian akhir semester, dan ujian sekolah. Hal ini dimaksudkan untuk melatih dan mengetahui kategori kemampuan berpikir tingkat tinggi siswa.

Akan tetapi pada kajian penelitian oleh Schulz \& FitzPatrick (2016) menemukan para guru menunjukkan ketidakpastian tentang konsep HOTS dan mereka tidak siap untuk mengajar atau menilai HOTS. Hasil kajian selanjutnya oleh Retnawati (2018) menunjukkan bahwa pengetahuan guru tentang HOTS, kemampuan mereka untuk meningkatkan HOTS siswa, memecahkan masalah berbasis HOTS, dan kegiatan mengukur HOTS siswa masih rendah. Temuan yang serupa diperoleh Driana dan Ernawati (2019), guru sekolah dasar yang berpartisipasi dalam penelitiannya belum memiliki pemahaman komprehensif tentang HOTS. Sehingga kurangnya kegiatan pelatihan dan pengukuran kemampuan berpikir tingkat tinggi siswa. Permasalahan utama juga ditemukan pada observasi penelitian. Pada observasi yang dilakukan di SDN 1 Padang Sambian melalui pernyataan Kepala Sekolah yang mengatakan bahwa, sekolah sadar betul tentang pentingnya pengembangan kemampuan berpikir tingkat tinggi siswa untuk daya saing. Guru-guru disekolah tersebut juga sudah mengikuti workshop atau seminar mengenai pengembangan soal dan penilaian HOTS, namun pelaksanaanya belum sepenuhnya optimal. Mengingat soal ulangan harian, ataupun soal penilaian kenaikan kelas masih pada ranah C1 sampai C3 saja, terdapat C4 namun tidak banyak. Melalui hasil observasi tersebut, dapat diartikan bahwa belum diketahuinya kategori kemampuan berpikir tingkat tinggi yang dimiliki masing-masing siswa. Pada bagian yang lebih luas hal tersebut berdampak pada kesiapan siswa dalam menghadapi masalah yang lebih kompleks di abad 21. Belum terdapatnya kegiatan pelatihan dan pengukuran kemampuan tersebut berdampak pada rendahnya kemampuan siswa pada ranah kognitif analisis, evaluasi dan mencipta, hal tersebut berdasarkan kajian Yuliati dan Lestari (2018). Agar HOTS siswa berkembang dengan baik, siswa perlu dibiasakan pengukuran melalui HOTS, jika tidak akan menyebabkan potensi HOTS dalam diri siswa tidak berkembang Arifin dan Retnawati (2017:11).

Penjelasan oleh Budiarta (2018:103) menyebutkan HOTS dapat dimaknai sebagai kemampuan proses berpikir kompleks yang mencangkup mengurai materi, mengkritisi serta menciptakan solusi pada pemecahan masalah. Menanggapi hal yang sama, Thomas dan Thorne (2009) mendefinisikan HOTS sebagai kemampuan berpikir dengan membuat keterkaitan antar fakta terhadap sebuah permasalahan. Pemecahan masalah yang dilakukan tidak sekedar melalui proses mengingat atau menghafal saja, namun menuntut untuk membuat hubungan dan kesimpulan dari permasalahan. Menyertai hal yang serupa Annuuru,dkk (2017:137) menjelaskan HOTS merupakan kemampuan menggabungkan fakta dan ide dalam proses menganalisis, mengevaluasi sampai pada tahap mencipta berupa memberikan penilaian terhadap suatu fakta yang dipelajari atau bisa mencipta dari sesuatu yang telah dipelajari.

Proses menganalisis, mengevaluasi serta mencipta merupakan bagian dari taksonomi kognitif yang dibuat oleh Benjamin S. Bloom pada tahun 1956. Pada akhirnya disempurnakan kembali oleh Anderson dan Krathwohl (2001) menjadi C1-ingatan (remembering), C2-pemahaman (understanding), C3- 
menerapkan (applying), C4-analisis (analysing), C5-evaluasi (evaluating), dan C6-kreasi (creating). Tanujaya (2017:78) menjelaskan level satu sampai tiga merupakan kemampuan berpikir tingkat rendah atau LOTS (Lower Order Thinking Skill) dan level empat sampai enam merupakan HOTS (Higher Order Thinking Skill). Maka jika ditinjau dari ranah kognitif HOTS merupakan kemampuan menganalisis, mengevaluasi serta mencipta. Bersumber pada hal tersebut Sulianto (2018:10) menyajikan gambar tingkat kognitif pada taksonomi Bloom revisi pada gambar 1.

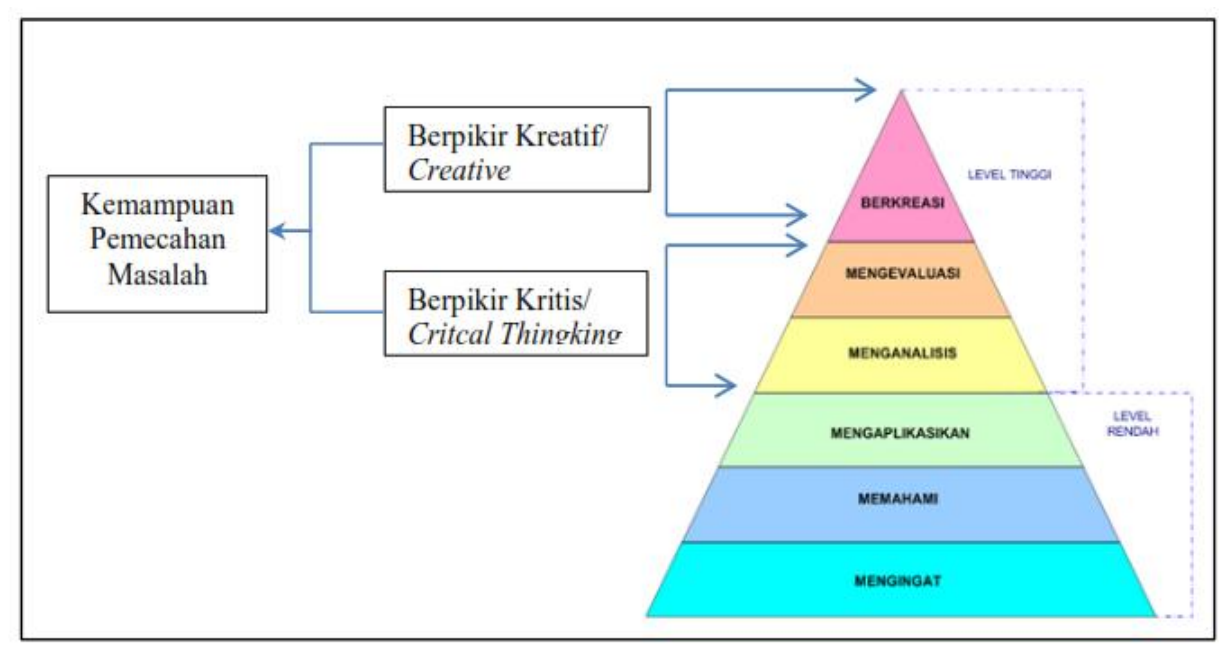

Gambar 1

Taksonomi Kognitif HOTS

Gambar 1 tersebut meliputi proses C4 dan C5 sebagai berpikir kritis, sedangkan C6 bagian dari kemampuan berpikir kreatif, kemampuan proses berpikir kritis dan kreatif digunakan untuk memecahkan masalah atau mencipta solusi untuk menetapkan keputusan. Ketiga proses kognitif tersebut tergerak ketika menemukan permasalah baru yang, kesuksesan kemampuan berpikir tingkat tinggi terdapat pada keberhasilan seseorang dalam menggerakan ketiga proses berpikir tersebut Saido (2015:14). Adaptasi dari pendapat Anderson dan Krathwohl (2001:68), Wahyuni (2018:85) serta Anggraini (2019:3) dapat dirangkum makna serta indikator dari ketiga level kognitif HOTS terdapat pada tabel 1.

Tabel 1. Level Kognitif dan Indikator Kognitif HOTS

\begin{tabular}{ccc}
\hline Aspek & $\begin{array}{c}\text { Level Kognitif } \\
\text { dan Indikator }\end{array}$ & Definisi \\
\hline $\begin{array}{c}\text { Berpikir } \\
\text { Kritis }\end{array}$ & C4-Menganalisis & Proses mengurai materi yang kemudian dicari kaitannya secara \\
& keseluruhan
\end{tabular}




\begin{tabular}{ccc}
\hline $\begin{array}{c}\text { Pemecahan } \\
\text { Masalah }\end{array}$ & Merencana & Mampu merancang suatu cara untuk menyelesaikan masalah \\
\cline { 2 - 2 } & Memproduksi & Mampu membuat ide, solusi atau keputusan dari rancangan yang \\
dibuat sebelumnya
\end{tabular}

Jadi sesunguhnya HOTS didefinisikan sebagai kemampuan yang melibatkan daya pikir kritis serta kreatif untuk memecahan suatu masalah. Seseorang dengan kemampuan berpikir tingkat tinggi harus mampu menganalisis, menghubungkan, mengurai serta memaknai permasalahan untuk memperoleh solusi atau ide baru. HOTS sendiri merupakan bagian dari ranah kognitif yang ada dalam Taksonomi Bloom revisi. HOTS berada pada level menganalisis, mengevaluasi hingga mencipta.

Kemampuan menganalisis, mengevaluasi serta mencipta seperti yang dijelaskan oleh Kementerian Pendidikan dan Kebudayaan (2014) telah menjadi SKL (Standar Kompetensi Lulusan) di jenjang pendidikan SD (Sekolah Dasar) pada ranah pengetahuan dan keterampilan. Pada bagian tersebut juga dijelaskan bahwa pengembangan Kurikulum 2013 diharapkan mampu membentuk pribadi dengan daya pikir dan tindak yang produktif dan kreatif (Kurniasih \& Sani, 2014). Menanggapi hal tersebut Sulis (2019:553) menyatakan bahwa penerapan HOTS pada evaluasi pembelajaran tercermin melalui soal-soal yang harus diselesaikan oleh siswa. Soal-soal yang diberikan tidak hanya terbatas pada level aplikasi (C3) tetapi juga sampai level mencipta (C6). Soal HOTS ialah soal yang melibatkan bagian kognitif C4 analisis, C5 evaluasi, dan C6 kreasi (Surata, 2018, p. 3). Hal yang sama diungkapkan oleh Setiawati (2019:38) bahwa soal HOTS merupakan soal yang berada pada ranah dimensi berpikir menganalisis, mengevaluasi serta mencitpa. Soal HOTS melibatkan masalah nyata, melalui nalar serta logika siswa diharapkan mampu memecahkan masalah tersebut. Selain itu Widana (2017:36) juga menjelasakan soal HOTS sebagai soal yang menuntut siswa untuk berpikir kritis dan kreatif untuk menjawab soal. Singkatnya Hanifah (2019:6) menjelaskan soal HOTS merupakan instrumen yang sengaja dirancang guna mengukur kemampuan berpikir tinggi. Maka soal HOTS merupakan soal yang memuat ranah kognitif C4 sampai C6, itu berarti kemampuan berpikir tingkat tinggi seseorang dapat diukur menggunakan soal HOTS. Soal HOTS dapat diorientasikan pada tiap mata pelajaran. Khususnya mata pelajaran matematika yang sudah terlepas dari tema untuk kelas IV hingga VI sekolah dasar.

Mata pelajaran matematika menurut Hamdi (2018:126) adalah salah satu bidang pengetahuan yang memiliki peran sentral dalam pengembangan kompetensi yang dibutuhkan untuk menghadapi lingkungan abad 21. Pemahaman matematika adalah pusat kesiapan generasi muda untuk hidup dalam masyarakat modern. Wicasari dan Ernaningsih (2016:250) menambahkan bahwa dengan mengasah logika melalui pembelajaran matematika sama halnya dengan melatih kemampuan berpikir tingkat tinggi. Sebagai dasar ilmu berkembangnya pengetahuan dan teknologi modern, matematika serta berperan memajukan daya pikir manusia. Pada berbagai bidang, cabang ilmu ini berguna untuk menyelesaikan masalah hingga akhirnya digunakan sebagai standar yang menentukan kemajuan pendidikan di suatu negara (Pratama dan Retnawati,2018:1). Mata pelajaran matematika memberikan bekal kemampuan berpikir logis, analisis, sistematis, kritis, inovatif serta kemampuan bekerjasama, mata pelajaran ini perlu diberikan sejak jenjang pendidikan dasar. Melalui mata pelajaran matematika diharapkan siswa mampu menerapkan kegunaannya pada kehidupan sehari-hari (Widana,2019:14). Begitu pula Suarjana (2017:104) menyatakan, mata pelajaran matematika diperlukan setiap orang untuk menyelesaikan berbagai masalah, melalui proses berhitung serta berpikir. Mampu menyelesaikan masalah berarti mampu menelaah suatu permasalahan dan mampu menggunakan pengetahuannya ke dalam situasi baru. Kemampuan inilah yang biasanya dikenal sebagai Higher Order Thingking Skills (Dinni, 2018, p. 107). Bersumber pada pendapat tersebut mata pelajaran matematika merupakan komponen pengajaran yang menjadi dasar perkembangan bidang-bidang pengajaran lainya, dengan sifatnya yang universal matematika dapat memajukan daya pikir manusia yang digunakan untuk menemukan jalan keluar dari masalah melalui proses berhitung serta berpikir. Pentingnya peran matematika untuk meningkatkan serta mengetahui kemampuan berpikir HOTS siswa dapat diimplementasikan dalam kegiatan analisis.

Kegiatan analisis kemampuan berpikir tingkat tinggi ini berguna sebagai rekam jejak proses pembelajaran yang telah berlangsung sebelumnya. Melalui hasil kajian oleh Azizah (2018) menyebutkan kegiatan analisis kemampuan berpikir tingkat tinggi merupakan solusi untuk mendeskripsikan kemampuan HOTS yang dimilki siswa. Pengembangan kemampuan berpikir tingkat tinggi siswa juga dapat ditempuh melalui kegiatan analisis ini, sesuai dengan kajian oleh Wiwin (2017). Seperti hasil kajian oleh Intan \& Kuntarto (2020) yang menemukan kemampuan berpikir tingkat tinggi siswa kelas V SD Negeri No.55/I Sridadi berada pada kategori cukup dengan rata-rata nilai yang diperoleh adalah 64,77. Hasil tersebut juga menunjukkan kemampuan siswa masih rendah pada ranah kognitif C6 (mencipta). Kajian tersebut memperoleh hasil kategori yang sama pada penelitian ini yaitu kemampuan berpikir tingkat tinggi siswa kelas V SD dalam menjawab soal HOTS mata pelajaran matematika berada pada kategori cukup serta rendahnya kemampuan siswa dalam menjawab soal ranah kognitif C6 (mencipta). 
Intan dan Kuntarto menggunakan nilai rata-rata sebagai pembagian kategori kemampuan berpikir HOTS sedangkan penelitian ini menggunakan PAP sebagai pembagian kategori kemampuan berpikir HOTS. Penelitian oleh Intan dan Kuntarto hanya berfokus pada kemampuan berpikir tingkat tinggi, tanpa memuat bahasan mengenai kendala siswa menjawab soal HOTS mata pelajaran matematika. Pada hasil kajian tersebut juga disebutkan untuk mengetahui kemampuan berpikir tingkat tinggi diperlukan kegiatan analis. Maka dari itu kegiatan analisis penting dilakukan guna mengetahui kemampuan siswa berpikir tingkat tinggi yang dimiliki siswa. Kegiatan analisis dilakukan untuk mengetahui kategori kemampuan berpikir tingkat tinggi yang dimiliki siswa serta penyebab siswa yang memiliki rendah belum mencapai kemampuan yang diharapkan. Setelah mengetahui letak kekurangan siswa, guru dapat menentukan langkah selanjutnya untuk mengoptimalkan daya pikir siswa. Pelaksaan penelitian ini dilakukan dengan menyebarkan soal HOTS mata pelajaran matematika pada siswa kelas V, yang kemudian dilanjutkan dengan sesi wawancara untuk mengetahui kendala siswa dalam menyelesaikan soal HOTS tersebut. Bersumber pada pembahasan tersebut maka tujuan penelitian ini adalah mengetahui kemampuan berpikir tingkat tinggi siswa serta mengetahui kendala siswa dalam menjawab soal HOTS mata pelajaran matematika.

\section{Metode}

Penelitian ini tergolong jenis penelitian deskriptif. Penelitian deskriptif yang dilaksanakan tidak bertujuan mencari hubungan antar variabel atau menguji hipotesis. Penelitan ini hanya memiliki satu variabel mandiri yaitu kemampuan berpikir tingkat tinggi. Adapun teknik sampling yang digunakan dalam penelitian ini yaitu teknik sampling jenuh yang merupakan teknik penentuan sampel dengan menggunakan seluruh populasi sebagai subjek penelitian. Maka sampel penelitian ini memiliki jumlah yang sama dengan populasi yaitu 85 siswa kelas V SDN 1 Padang Sambian Tahun Ajaran 2019/2020. Pengambilan data pada seluruh populasi dilakukan melalui instrumen tes uraian dan wawancara.

Instrumen tes yang digunakan adalah soal HOTS mata pelajaran matematika, yang terdiri dari 6 butir soal. Lembar jawaban siswa dinilai menggunakan rubrik penilaian dengan skor tertinggi ialah 60 dan skor terendah adalah 0 . Hasil skor akhir tersebut kemudian dianalisis menggunakan teknik analisis PAP (Penilaian Acuan Patokan), sesuai hakikatnya PAP ialah standar lulus (batas lulus - gagal) yang telah ditetapkan sebagai patokan sejak awal penilaian itu akan dilaksanakan (Yusuf,2017:251). Maka berdasarkan panduan penilaian siswa sekolah dasar dapat di peroleh nilai PAP, pad tabel 2.

Tabel 2. Panduan Penilaian Siswa Sekolah Dasar

\begin{tabular}{cc}
\hline Interval Nilai & Kategori \\
\hline $\mathbf{8 8}-\mathbf{1 0 0}$ & Sangat Baik \\
\hline $\mathbf{7 4 - 8 7}$ & Baik \\
\hline $\mathbf{6 0 - 7 3}$ & Cukup \\
\hline $\mathbf{0}-\mathbf{5 9}$ & Kurang/perlu bimbingan \\
\hline
\end{tabular}

Kemudian dikonversi dengan rumus sebagai berikut:

skor $=\frac{\text { interval nilai }}{100} x$ skor maksimal

Maka diperoleh Penilaian Acuan Patokan skor pada tabel 3.

Tabel 3. PAP Kategori Kemampuan Berpikir Tingkat Tinggi (HOTS)

\begin{tabular}{cc}
\hline Skor & Kategori \\
\hline $\mathbf{5 3}-\mathbf{6 0}$ & Kemampuan Berpikir HOTS Tinggi \\
\hline $\mathbf{4 5}-\mathbf{5 2}$ & Kemampuan Berpikir HOTS \\
\hline $\mathbf{3 6 - 4 4}$ & Kemampuan Berpikir HOTS Cukup \\
\hline $\mathbf{0 - 3 5}$ & Kemampuan Berpikir HOTS Rendah \\
\hline
\end{tabular}


Mengetahui syarat instrumen yang baik adalah valid dan reliabel maka secara berturut-turut jenis validitas dan reliabelitas yang digunakankan adalah validitas konstruk dan reliabilitas kappa. Melalui validitas konstruk soal HOTS mata pelajaran matematika telah dinyatakan valid oleh 3 expert judgment. Sementara itu, cara kerja reliabilitas kappa dijelaskan oleh Widhiarso (2011:2) yang mengatakan bahwa, reliabilitas kappa dilakukan dengan menilai performa individu melalui checklist, dengan melibatkan konsistensi nilai dua orang rater. Jika semakin banyak kemiripan hasil penilaian antara satu rater dengan reter lainnya maka koefisien reliabilitas yang dihasilkan akan tinggi. Sebaliknya jika semakin sedikit kemiripan hasil penilaian antar rater dengan rater lainnya, maka koefisien realibilitasnya akan kecil. Berdasarkan hasil checklist yang sudah dipaparkan di atas, dapat dibuatkan tabel hasil penilaian antar rater penelitian ini dijabarkan dalam tabel 4 di bawah.

Tabel 4. Hasil Penilaian Antar Rater

\begin{tabular}{|c|c|c|c|c|c|c|c|}
\hline \multirow{2}{*}{$\begin{array}{c}\text { Penilai B } \\
\text { Kemampuan } \\
\text { Berpikir }\end{array}$} & \multicolumn{4}{|c|}{$\begin{array}{c}\text { Penilai A } \\
\text { Kemampuan Berpikir }\end{array}$} & \multirow[t]{2}{*}{ Total } & \multirow[t]{2}{*}{$\begin{array}{c}\text { Bentuk } \\
\text { desimal }\end{array}$} & \multirow[t]{2}{*}{$\begin{array}{c}\text { Hasil } \\
\text { Persen }\end{array}$} \\
\hline & $\begin{array}{l}\text { HOTS } \\
\text { Tinggi }\end{array}$ & HOTS & $\begin{array}{l}\text { HOTS } \\
\text { Cukup }\end{array}$ & $\begin{array}{c}\text { HOTS } \\
\text { Rendah }\end{array}$ & & & \\
\hline HOTS Tinggi & 16 & 0 & 0 & 0 & 16 & 0,188 & $18,82 \%$ \\
\hline HOTS & 0 & 22 & 0 & 0 & 22 & 0,259 & $25,88 \%$ \\
\hline HOTS Cukup & 0 & 0 & 44 & 1 & 45 & 0,529 & $52,94 \%$ \\
\hline HOTS Rendah & 0 & 0 & 0 & 2 & 2 & 0,024 & $2,35 \%$ \\
\hline Total & 16 & 22 & 44 & 3 & 85 & & \\
\hline Bentuk Desimal & 0,188 & 0,259 & 0,518 & 0,035 & & & \\
\hline Hasil persen & $18,82 \%$ & $25,88 \%$ & $51,76 \%$ & $3,5 \%$ & & & \\
\hline
\end{tabular}

Dari hasil perhitungan antar rater yang dijabarkan pada tabel 4 di atas, didapatkan peneilaian terhadap soal HOTS tinggi mencapai 16 setara 18,82\%, HOTS mencapai 22 setara 25,88\%, HOTS cukup mencapai 44 setara 51,76\% dan HOTS rendah mencapai 3 setara 3,5\%. Hasil penilaian antar arter tersebut kemudian dilakukan penimbangan kesesuaian dan ketidaksesuaiannya. Hasil penimbangan tersebut di jabarkan pada tabel pada tabel 5 di bawah.

Tabel 5. Hasil Penimbang Sesuai Dan Tidak Sesuai

\begin{tabular}{cccccc} 
& & \multicolumn{2}{c}{ Faktor Penimbang } & & Total \\
& & Kemampuan Berpikir & \\
HOS Til Penimbang & HOTS Tinggi & HOTS & HOTS Cukup & HOTS Rendah & \\
\hline Sesuai & 16 & 22 & 44 & 2 & 84 \\
\hline Tidak Sesuai & 3,012 & 5,694 & 23,294 & 0,071 & 32,07 \\
\hline
\end{tabular}

Dari hasil penjabaran pada tabel 5 di atas, didapatkan hasil penimbangan sesuai mencapai total 84, sedangkan yang tidak sesuai mencapai 32,07. Selanjutnya, dari hasil perhitungan pada tabel di atas, dapat dihitung koefisien kappa dengan menggunakan rumus berikut.

$$
K=\frac{\operatorname{Pr}(\mathrm{a})-\operatorname{Pr}(\mathrm{e})}{1-\operatorname{Pr}(\mathrm{e})}
$$

(Warrens, 2015)

Keterangan:

$K \quad=$ Kappa

$\operatorname{Pr}(\mathrm{a})=$ Persentase jumlah pengukuran yang konsisten antar rater, dengan diperoleh nilai $\operatorname{Pr}(\mathrm{a})=0,988$

$\operatorname{Pr}(\mathrm{e})=$ Persentase jumlah perubahan pengukuran antar rater, dengan diperoleh nilai $\mathrm{P}(\mathrm{e})=0,377$

Hasil perhitungan reliabilitas kappa dengan mengikut sertakan 2 rater sebagai penimbang tersebut memperoleh koefisien kappa sebesar 0,981. Pada tabel interpretasi kappa oleh Warrens (2015) menyatakan 0,81 - 1,00 sangat baik maka hasil perhitungan 0,981 menyatakan nilai reliabilitas sangat baik atau sangat ajeg. Pada bagian berikutnya instrumen wawancara yang digunakan adalah pedoman wawancara dengan jenis wawancara tidak terstruktur untuk memperoleh data kendala siswa. Pada 
pedoman wawancara terdapat 3 pertanyaan yang mewakili masing-masing topik kendala: 1) tata bahasa soal, 2) membuat/membentuk kalimat matematika, serta 3) pemahaman materi. Pemberian wawancara bertujuan untuk mengetahui kendala siswa dalam menyelesaikan soal HOTS yang dikerjakan sebelumnya serta faktor-faktor penyebabnya. Hasil wawancara dianalisis dengan teknik analisis isi, sesuai hakikatnya teknik analisis isi merupakan cara yang digunakan untuk meringkas pesan-pesan yang tersampaikan pada teks atau media (Kimberly,2002:10)

\section{Hasil dan pembahasan}

\section{Hasil Data Kemampuan Berpikir Tingkat Tinggi Siswa}

Data kemampuan berpikir tingkat tinggi diperoleh dari hasil skor akhir siswa menjawab soal HOTS mata pelajaran matematika. Soal tersebut terdiri dari 6 soal mata pelajaran matematika dengan materi pecahan, kecepatan, jarak dan waktu. Lembar jawaban siswa dianalisis menggunakan rubrik penilaian bersama rater hingga memperoleh skor akhir siswa. Skor akhir siswa tersebut dianalisis menggunakan Penilaian acuan Patokan (PAP) yang telah dibuat sebelumnya. Skor akhir siswa juga dinalisis menggunakan statistika deskriptif guna memperoleh pemusatan skor yang diwakili oleh mean, median, modus serta penyebaran skor yang diwakili oleh standar deviasi. Maka kemampuan berpikir tingkat tinggi siswa dapat dinyatakan pada gambar 2 di bawah.

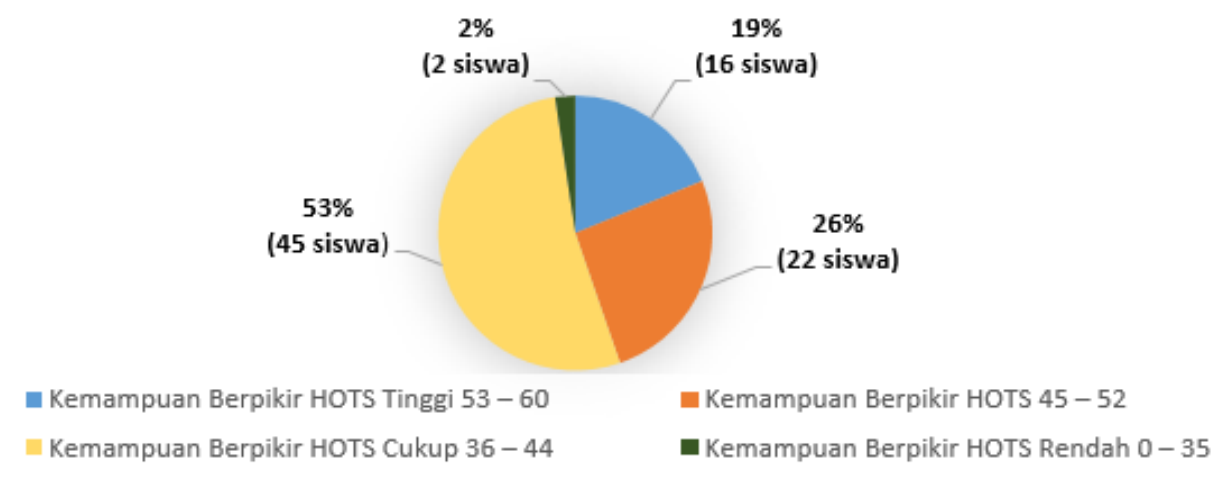

Gambar 2

Analisis Kemampuan Berpikir Tingkat Tinggi Siswa

Dari hasil analisis PAP kemampuan berpikir kritis siwa pada gambar 2 menunjukan dari 85 siswa, diperoleh hasil sebanyak 16 siswa (19\%) memiliki Kemampuan Berpikir HOTS Tinggi, sebanyak 22 siswa (26\%) memiliki Kemampuan Berpikir HOTS, sebanyak 45 siswa (53\%) memiliki Kemampuan Berpikir HOTS Cukup, serta 2 siswa (2\%) memiliki Kemampuan Berpikir HOTS Rendah. Sedangkan nilai pemusatan dan penyebaran data skor siswa dijabarkan pada tabel 6 di bawah.

Tabel 6. Analisis Skor siswa

\begin{tabular}{cc}
\hline Skor Tertinggi & $\mathbf{6 0}$ \\
\hline Skor Terendah & 24 \\
\hline Mean & 46,859 \\
\hline Modus & 44 \\
\hline Median & 44 \\
\hline Standar Deviasi & 7,788 \\
\hline
\end{tabular}

Dari hasil analisis skor siswa pada tabel 6 menunjukkan nilai modus adalah 44, bila dikonversi pada penilai PAP maka kemampuan berpikir HOTS tergolong cukup. Pada bagian tersebut juga menunjukkan bahwa skor siswa mampu meraih skor tertinggi yaitu 60, sedangkan skor terendah berada pada nilai 24 . Maka berdasarkan analisis PAP menunjukkan bahwa siswa kelas V SDN 1 Padang Sambian cenderung 
memiliki Kemampuan Berpikir HOTS Cukup. Kemudian untuk mengetahui pencapaian siswa pada ranah kognitif HOTS, maka serta merta dilakukan analisis skor pada tiap soal pada tabel 7.

Tabel 7. Pencapaian Skor Pada Tiap Soal

\begin{tabular}{ccccccc}
\hline Nomor Soal & $\mathbf{1}$ & $\mathbf{2}$ & $\mathbf{3}$ & $\mathbf{4}$ & $\mathbf{5}$ & $\mathbf{6}$ \\
\hline Skor Maksimal & 10 & 10 & 10 & 10 & 10 & 10 \\
\hline Jumlah Skor Maksimal & 850 & 850 & 850 & 850 & 850 & 850 \\
\hline Jumlah Skor & 743 & 573 & 668 & 698 & 584 & 717 \\
\hline Persentase & $88 \%$ & $67 \%$ & $79 \%$ & $82 \%$ & $69 \%$ & $84 \%$ \\
\hline Nilai Tertinggi & 10 & 10 & 10 & 10 & 10 & 10 \\
\hline Nilai Terendah & 7 & 0 & 6 & 6 & 4 & 0 \\
\hline Mean & 8,741 & 6,741 & 7,859 & 8,212 & 6,872 & 8,435 \\
\hline Modus & 8 & 6 & 7 & 8 & 7 & 8 \\
\hline Median & 8 & 6 & 7 & 8 & 7 & 8 \\
\hline Standar Deviasi & 1,135 & 1,800 & 1,311 & 1,124 & 1,624 & 1,492 \\
\hline
\end{tabular}

Tabel 7 menunjukkan persentase pencapaian skor siswa pada tiap soal. Skor maksimum soal nomor 1 adalah 10, sehingga apabila 85 siswa peserta tes mendapat skor masing-masing 10 maka skor maksimum dari soal tersebut adalah 10 di kali 85 atau 850. Akan tetapi pada kenyataannya, jumlah skor maksimum yang diperoleh 85 siswa adalah 774, sehingga persentase skor jawaban siswa pada soal nomor 1 dari hasil tersebut adalah 88\%. Mengingat kembali soal nomor 1 dan 4 merupakan soal dengan ranah kognitif C4, soal nomor 3 dan 6 termasuk ranah kognitif C5 sedangkan soal nomor 2 dan 5 ranah kognitif C6. Berkaitan dengan hal tersebut hasil persentase pada tabel juga menunjukkan kemampuan siswa masih rendah dalam menjawab soal dengan ranah kognitif C6.

\section{Hasil Data Wawancara}

Pelaksanaan kegiatan wawancara dilakukan setelah siswa menyelesaikan soal HOTS mata pelajaran matematika. Kegiatan wawancara dibantu dengan alat perekam suara, yang kemudian ditranskrip hingga kemudian dianalisis menggunakan teknik analisis isi. Maka berdasarkan wawancara yang dilakukan kepada 85 siswa diperoleh hasil datamengenai kendala siswa menyelesaikan soal HOTS mata pelajaran matematika menunjukkan hasil yang terdapat pada tabel 8 .

Tabel 8. Rangkuman Kendala Siswa Kelas V Mengerjakan Soal HOTS

\begin{tabular}{|c|c|c|c|}
\hline Kendala & $\begin{array}{c}\text { Banyak } \\
\text { Siswa }\end{array}$ & Persen & Rangkuman Hasil Wawancara \\
\hline Tata Bahasa & 26 & $31 \%$ & $\begin{array}{c}\text { Siswa menyatakan tata bahasa sebagai kendala dengan alasan } \\
\text { siswa merasa tulisannya terlalu banyak dan harus banyak } \\
\text { membaca membuat lama saat menjawab. Siswa juga jarang } \\
\text { diberi latihan soal cerita }\end{array}$ \\
\hline $\begin{array}{l}\text { Membuat/ } \\
\text { Membentuk } \\
\text { Kalimat } \\
\text { Matematika }\end{array}$ & 53 & $62 \%$ & $\begin{array}{l}\text { Siswa menyatakan membentuk kalimat matematika sebagai } \\
\text { kendala dengan alasan karena siswa masih bingung untuk } \\
\text { menentukan langkah pengerjaan soal, seperti penentuan cara } \\
\text { untuk memecahkan masalah karena harus mencari tahu } \\
\text { sendiri masalah apa yang harus dipecahkan. }\end{array}$ \\
\hline $\begin{array}{l}\text { Pemahaman } \\
\text { Materi }\end{array}$ & 6 & $7 \%$ & $\begin{array}{c}\text { Siswa menyatakan pemahaman materi sebagai kendala } \\
\text { dengan alasan karena siswa lupa dengan materi pecahan } \\
\text { serta kecepatan jarak dan waktu. }\end{array}$ \\
\hline
\end{tabular}

Berdasarkan tabel 8, siswa kelas V SDN 1 Padang Sambian cenderung mengalami kesulitan saat membuat/membentuk kalimat matematika. Pada tiap topik kendala yang dialami, siswa memiliki alasan yang cukup beragam. Melalui alasan yang telah dirangkum peneliti dapat menyajikan faktor-faktor penyebab kendala yang dialami siswa dalam menyelesiakan soal HOTS mata pelajaran matematika, yaitu: 1) kurangnya latihan soal berorientasi HOTS, 2) kemalasan siswa membaca soal dengan kalimat yang panjang, 3) kebingunan siswa menentukan cara yang digunakan menjawab soal dan 4) kurangnya pemahaman materi kecepatan, jarak waktu serta pecahan. 


\section{Pembahasan}

Data kemampuan berpikir tingkat tinggi siswa dalam mengerjakan soal HOTS pada mata pelajaran matematika di kelas V SDN 1 Padang Sambian diperoleh dari tes yang disusun berdasarkan tiga ranah kognitif HOTS yaitu menganalisis, mengevaluasi, dan mencipta. Bersumber pada hasil analisis menunjukkan siswa cenderung memiliki Kemampuan Berpikir HOTS Cukup serta serta masih rendah dalam menyelesaikan soal ranah kognitif C6 (mencipta). Hasil kajian relevan oleh Alfiatin \& Oktiningrum (2019) yang menemukan kemampuan berpikir tingkat tinggi siswa kelas V SD Imam Bonjol berada pada kategori cukup dengan rata-rata nilai yang diperoleh adalah 67,85. Hasil tersebut juga menunjukkan kemampuan siswa masih rendah pada ranah kognitif C6 (mencipta). Tak dapat dipungkiri hasil tersebut akibat dari, tidak terbiasanya siswa dalam mengerjakan soal tipe HOTS. Siswa cenderung terbiasa dengan pembelajaran dan pemberian soal betipe LOTS. Mengingat soal ulangan harian, ataupun soal penilaian kenaikan kelas masih pada ranah C1 sampai C3 saja (LOTS), terdapat C4 namun tidak banyak seperti pernyataan Kepala Sekolah saat kegiatan observasi. Tidak hanya pemberian soal bertipe HOTS yang menjadi sorotan, namun juga cara siswa mengatur atau merancang cara menjawab soal yang dimulai dari membuat diketahui, ditanya hingga dijawab. Kemampuan berpikir HOTS cukup serta rendahnya kemampuan menjawab soal ranah kognitif C6 juga akibat dari, kurangnya latihan untuk membuat rancangan langkah penyelesaian masalah pada soal. Kendala pada membuat rancangan langkah penyelesaian soal tersebut juga diakui siswa pada sesi wawancara.

Tercatat pada hasil analisis kendala menyeselesaikan soal HOTS siswa cenderung mengalami kesulitan saat membuat/membentuk kalimat matematika. Pada faktor kendala siswa juga disebut siswa jarang mengerjakan bentuk uraian berbasis masalah (soal cerita) sehingga siswa belum terbiasa menentukan cara apa yang digunakan untuk menjawab soal tersebut. Hakikatnya soal bentuk uraian ialah soal yang dirancang dengan menuntut siswa untuk mengorganisasikan jawabannya sendiri. Siswa berkesempatan memberikan jawaban dengan cara yang berbeda-beda namun tetap terbuka memperoleh nilai yang sama. Soal bentuk uraian berguna untuk mengukur hasil belajar peserta didik serta kemampuan berpikir siswa (Murti,2018:24). Siswa juga terbiasa dengan bentuk soal pilihan ganda dengan cara menjawab soal tanpa disertai penulisan cara atau langkah-langkah memperoleh jawaban. Hasil penelitian relevan yaitu oleh Hidayanti (2019) yang melakukan penelitian kepada 17 siswa kelas V SDN 1 Tulusrejo 3 Kota Malang. Hasil penelitian menunjukkan sebanyak 70,16\% siswa mengalami kesulitan atau kendala dalam memahami maksud soal hingga kesulitan menerjemahkannya menjadi kalimat matematika. Bersumber pada teori Wilson (2000) penyebab kendala yang dialami siswa tersebut ialah kegiatan pembelajaran yang masih berbasis hanya transformasi ilmu hanya berpangkal pada ranah kognitif C1, C2 dan C3 saja atau LOTS, tanpa kegiatan mengkritisi dan menemukan yang berada pada ranah C4 hingga C6 atau HOTS. Sehingga siswa kesulitan dalam menjawab soal berupa aplikasi. Siswa cenderung melakukan kesalahan menjawab soal karena soal yang diberikan berbeda dengan prosedur yang diberikan oleh gurunya.

Pada pelaksaan penelitian soal HOTS yang dikerjakan siswa terdiri dari 6 butir soal uraian, yang tiap 2 soalnya mewakili ranah kognitif HOTS. Soal dengan ranah kognitif C4 (menganalisis) berkaitan dengan kemampuan siswa mengurai serta mengidentifikasi informasi pada soal menjadi struktur yang terorganisir, seperti menulis diketahui, ditanya serta hasil jawaban. Pada soal dengan ranah kognitif C5 (mengevaluasi) berkaitan dengan kemampuan siswa mengambil keputusan atau membuat penilaian terhadap suatu cara agar selaras dengan target. Pada soal dengan ranah kognitif C6 (mencipta) berkaitan dengan kemampuan siswa mengatur cara pengerjaan soal dan membuat langkah pengerjaan sehingga dapat memperoleh pemecahan masalah serta menciptakan banyak solusi dari permasalahan pada soal. Menurut Yuliati \& Lestari (2018:182) soal dengan ranah kognitif analisis, evaluasi, dan kreasi membutuhkan penyelesaian yang lebih kompleks, karena merupakan ranah kemampuan berpikir tingkat tinggi. Selaras dengan pendapat Nurhasanah (2018:525) bahwa kemampuan berpikir tingkat tinggi merupakan proses berpikir yang tidak sekedar menghafal dan menyampaikan kembali informasi yang diketahui. Kemampuan berpikir ingkat tinggi merupakan kemampuan menghubungkan, memanipulasi, dan menstransformasi pengetahuan serta pengalaman yang sudah dimiliki untuk berpikir secara kritis dan kreatif dalam upaya menentukan keputusan dan memecahkan masalah. HOTS menurut Arifin dan Retnawati (2017:99) merupakan kemampuan berpikir kompleks yang melibatkan segala aspek sebelumnya hingga menghasilkan solusi. Oleh karena itu, apabila pengetahuan awal sudah kuat maka

Putu Manik Sugiari Saraswati ${ }^{1}$ Gusti Ngurah Sastra Agustika ${ }^{2} /$ Kemampuan Berpikir Tingkat Tinggi Dalam Menyelesaikan Soal HOTS Mata Pelajaran Matematika 
siswa akan semakin mudah menaiki tangga ranah kognitif yang lebih tinggi. Hal tersebut berarti untuk untuk menyelesaikan soal dengan tingkat lebih tinggi dibutuhkan satu kesatuan level kemampuan dibawahnya, seperti untuk menyelesaikan soal tingkat C6-mencipta diperlukan juga kemampuan C4menganalisis dan C5-mengevaluasi (Nugroho,2018:59). Pada bagian sebelumnya telah dijelaskan bahwa HOTS berada ranah kognitif taksonomi bloom, yang kemudian disempurnakan oleh Anderson dan Krathwohl (2001) menjadi C1-ingatan (remembering), C2-pemahaman (understanding), C3-menerapkan (applying), C4-analisis (analysing), C5-evaluasi (evaluating), dan C6-kreasi (creating). Budiarta (2018:103) menjelaskan level satu sampai tiga merupakan kemampuan berpikir tingkat rendah atau LOTS (Lower Order Thinking Skill) dan level empat sampai enam merupakan HOTS (Higher Order Thinking Skill). LOTS sesuai dengan penjelasan Sani (2019:41) merupakan kemampuan bersifat mekanis yang terbatas pada hal-hal rutin, seperti menghafal dan hanya mengulang informasi yang telah diketauhi sebelumnya tanpa adanya kegiatan mengkritisi dan mengembangkan ide baru. Pada pembelajaran dikelas LOTS tercemin pada kegiatan pembelajaran satu arah yang domain oleh guru dan hanya memberikan sedikit kesempatan pada siswa untuk berpikir aktif, selain itu juga tercermin pada kegiatan pengukuran yang hanya mengandalkan pertanyaan yang bersifat ingatan (Yuliati \& Lestari,2018:182). Sebaliknya HOTS menurut Anggraini (2019:2), merupakan kemampuan yang tidak sekedar mengandalkan ingatan, namun usaha berpikir kompleks yang melibatkan berpikir kreatif dan kritis terhadap suatu permasalahan untuk menemukan solusi. Pada pembelajaran di kelas HOTS tercermin pada pembelajaran dua arah yang, antara guru dan siswa, siswa diberikan kesempatan lebih banyak mencari dan menemukan dengan cara mereka untuk memecahan permasalahan, begitu pula pada kegiatan pengukuran mengutamakan pertanyaan yang berupa permasalahan, pencarian informasi, analitif, evaluatif dan pembuatan keputusan (Sani, 2019:62).

Merujuk pada pendapat Brookhart (2010:3) pada pembelajaran HOTS dibagi menjadi 3 yaitu HOTS sebagai transfer, HOTS sebagai berpikir kritis serta HOTS sebagai pemecah masalah. Ketika menghadapi masalah seseorang perlu memiliki keterampilan untuk mengaplikasikan pengetahuannya, kemudian membuat penilaian yang bijak serta mampu mengkritisi dengan memberikan alasan logis dan ilmiah dan akhirnya menyelesaikan masalah menggunakan strategi yang telah dibuat sebelumnya. Begitu pula FJ, King (2006) menjelaskan HOTS tidak terlepas dari tingkat pembelajaran, tiap level kognitif saling bergantung. Hal yang dipelajaran sebelumnya dapat membantu mengoptimalkan kemampuan berpikir tingkat tinggi. Menyelesaikan soal HOTS seperti menaiki anak tangga. Untuk menjawab soal soal tingkat C5 (mengevaluasi) perlu menguasai kemampuan C4 (menganalisis), C3 (menerapkan), C2 (memahami) serta C1 (mengingat) dan begitu pula dengan tingkat soal yang lain. Menanggapi hal tersebut Retnawati (2018:216) menjelaskan perlunya membiasakan siswa dengan kegiatan pembelajaran dan pengukuran HOTS adalah penting untuk mengembangkan ide atau solusi dari permasalahan yang rumit. Sesuai dengan hakikatnya manusia diciptakan berbeda, setiap siswa juga memiliki kemampuan yang berbeda untuk mencapai keenam level kognitif tersebut. Pada penelitian ini khusus dibahas kemampuan berpikir tingkat tinggi yang dimiliki masing-masing siswa. Hasil penelitian ini menunjukkan: 1) siswa kelas V SDN 1 Padang Sambian Tahun Ajaran 2019/2020 cenderung memiliki Kemampuan Berpikir HOTS Cukup serta masih rendah dalam menyelesaikan soal ranah kognitif C6, dan 2) siswa kelas V SDN 1 Padang Sambian cenderung mengalami kesulitan saat membuat/membentuk kalimat matematika.

\section{Simpulan dan saran}

Berdasarkan hasil penelitian dan pembahasan dapat dibuat beberapa simpulan, pertama hasil analisis PAP menunjukkan siswa kelas V SDN 1 Padang Sambian cenderung memiliki Kemampuan Berpikir HOTS Cukup serta masih rendah dalam menyelesaikan soal ranah kognitif C6. Kedua, pada hasil wawancara menunjukkan siswa kelas V SDN 1 Padang Sambian cenderung mengalami kesulitan saat membuat/membentuk kalimat matematika. Simpulan yang diperoleh berimplikasi pada peningkatan kemampuan berpikir siswa tiap tingkat ranah kognitif melalui penilaian berbasis HOTS.

Terdapat beberapa saran yang bisa diberikan kepada siswa dan guru. Siswa disarankankan berlatih mengerjakan soal-soal matematika tipe HOTS, teurutama soal dengan level kreasi (C6) dan berupa soal kontekstual atau soal yang berkaitan dengan kehidupan sehari-hari. Hal ini dimaksud agar siswa terbiasa dapat menyelesaikan soal matematika yang beraneka ragam. Siswa diharapkan membiasakan diri menyelesaikan soal secara runtut dari memahami soal, merencanakan penyelesaian, melaksanakan rencana tersebut, dan melihat kembali kebenaran penyelesaian soal. Bagii guru, Guru disarankan mengetahui kemampuan siswa dalam menyelesaikan soal matematika tipe HOTS sehingga dapat merancang dan melakukan pembelajaran yang dapat meningkatkan kemampuan tersebut. Selain itu, guru hendaknya lebih sering memberikan penambahan tugas atau latihan soal HOTS. Guru disarankan melakukan penanaman konsep materi dengan baik dan secara runtut, begitu pula dalam hal penanaman konsep mengenai strategi penyelesaian suatu soal matematika. Guru diharapkan membiasakan siswa 
mengerjakan soal mata pelajaran matematika berorientasi HOTS secara runtut dari memahami soal, merencanakan penyelesaian soal, melaksanakan rencana tersebut, dan melihat kembali kebenaran penyelesaian soal. Agar ketika siswa menemukan berbagai macam soal matematika, siswa dapat menyelesaikannya dengan baik dan benar.

\section{Daftar Rujukan}

Alfiatin, A. L., \& Oktiningrum, W. (2019). Pengembangan Soal Higher Order Thinking Skills Berbasis Budaya Jawa Timur Untuk Mengukur Penalaran Siswa SD. Indiktika: Jurnal Inovasi Pendidikan Matematika, 2(1), 30-43. https://doi.org/10.31851/indiktika.v2i1.3395

Anderson, L. W., Krathwohl M. C. (2001). A Taxonomy for Learning, Teaching and Assesing. New York: Longman

Anggraini, N. P., Budiyono, \& Pratiwi, H. (2019). Analysis Of Higher Order Thinking Skills Students at Junior High School in Surakarta. Journal of Physics: Conference Series, 12(1), 1-9. https://doi.org/10.1088/1742-6596/1211/1/012077

Annuuru, T. A., Johan, R. C., \& Ali, M. (2017). Peningkatan Kemampuan Berpikir Tingkat Tinggi dalam Pelajaran Ilmu Pengetahuan Alam Peserta Didik Sekolah Dasar Melalui Model Pembelajaran Treffinger. Eduthecnologica, 3(2), 136-144.

Arifin, Z., \& Retnawati, H. (2017). Pengembangan Instrumen Pengukur Higher Order Thinking Skills Matematika Siswa SMA Kelas X. PYTHAGORAS: Jurnal Pendidikan Matematika, 12(1), 98-108. Brookhart, S. M. (2010). How to Assess Hinger Other Thingking Skill in Your Classroom. Virginia: ASCD.

Budiarta, K., Harahap, M. H., Faisal, \& Mailani, E. (2018). Potret Implementasi Pembelajaran Berbasis High Order Thinking Skills (HOTS) di Sekolah Dasar Kota Medan. Jurnal Pembangunan Perkotaan, 6(2), 102-111.

Dinni, H. N. (2018). HOTS ( High Order Thinking Skills ) dan Kaitannya dengan Kemampuan Literasi Matematika. Prisma, 1, 170-176.

Driana, E., \& E. (2019). Teachers' Understanding and Practices in Assessing Higher Order Thinking Skills at Primary Schools. Acitya: Journal of Teaching \& Education, 8(5), 620-628.

Faridah, E. M. I. (2019). Analisis Kemampuan Berpikir Kritis Siswa Melalui Soal-Soal HOTS ( Higher Order Thinking Skills ) Mata Pelajaran Sejarah Kelas X-IPS SMAN 2 SIDOARJO. AVATARA, e-Journal Pendidikan Sejarah, 7(3).

FJ, King., Ludwika, G., \& Faranak, R. (2006). Higher Order Thinking Skills, Definition, Teaching Strategies, Assessment. In Thinking (Vol. 18). Educational Services Program

Hamdi, S., Suganda, I. A., \& Hayati, N. (2018). Developing Higher-Order Thinking Skill (HOTS) Test Instrument Using Lombok Local Cultures As Contexts For Junior Secondary School Mathematics. Research and Evaluation in Education, 4(2), 126-135. https://doi.org/10.21831/reid.v4i2.22089

Hanifah, N. (2019). Pengembangan instrumen penilaian Higher Order Thinking Skill ( HOTS ) di Sekolah Dasar. Conference Series, 1(1), 1-8. http://ejournal.upi.edu/index.php/crecs/article/view/14286

Hidayanti, D. N. (2019). Analisis Kesalahan Penyelesaian Soal Cerita Matematika Bertipe HOTS Berdasarkan Teori Newman Pada Siswa Kelas $V \quad S D$. Universitas Muhammadiyah Malang. http://eprints.umm.ac.id/46121/

Intan, F. M., \& Kuntarto, E. (2020). Kemampuan Siswa dalam Mengerjakan Soal HOTS ( Higher Order Thinking Skills ) pada Pembelajaran Matematika di Kelas V Sekolah Dasar. Jurnal Pendidikan Dasar Indonesia, 5(1), 6-10.

Kimberley, N. (2002). The Content Analysis Guidebook. In ProQuest Central (p. 320). http://www.amazon.com/Content-Analysis-Guidebook-KimberlyNeuendorf/dp/0761919783/ref=sr_1_1?s=books\&ie=UTF8\&qid=1395675490\&sr=1$1 \&$ keywords=Content+analysis+guidebook+Neuendorf. 
Kurniasih, I., \& Sani, B. (2014). Implementasi Kurikulum 2013 Konsep dan Penerapan. Kementrian Pendidikan Dan Kebudayaan, 1-162.

Murti, Wiyanto, \& Hartono. (2018). Studi Komparasi antara Tes Testlet dan Uraian dalam Mengukur Hasil Belajar Kognitif Siswa Kelas XI SMA Negeri 1 Gombong. Unnes Physics Education Journal, 3(3), 77-83. https://doi.org/https://doi.org/10.15294/upej.v7i1.22469

Musrikah, M. (2018). Higher Order Thingking Skill (Hots) Untuk Anak Sekolah Dasar Dalam Pembelajaran Matematika. Martabat: Jurnal Perempuan Dan Anak, 2(2). https://doi.org/10.21274/martabat.2018.2.2.339-360

Nugroho, R. (2018). HOT (Kemampuan Berpikir Tingkat Tinggi: Konsep, Pembelajaran, Penilaian dan SoalSoal). PT Gramedia Widiasarana Indonesia.

Nurhasanah, N., \& Yarmi, G. (2018). Workshop Pengembangan Higher Order Thinking Skill ( HOTS ) Melalui Penerapan Pendekatan Saintifik Dalam Pembelajaran Di SDN Beji 1 Depok Jawa Barat. Prossiding Seminar Dan Diskusi Pendidikan Dasar, 523-528.

Pratama, G. S., \& Retnawati, H. (2018). Urgency of Higher Order Thinking Skills (HOTS) Content Analysis in Mathematics Textbook. Journal of Physics: Conference Series, 1097(1), 1-8. https://doi.org/10.1088/1742-6596/1097/1/012147

Pratiwi, N. P. W., Dewi, N. L. P. E. S., \& Paramartha, A. A. G. Y. (2019). The Reflection of HOTS in EFL Teachers ' Summative Assessment. Journal of Educational Research and Evaluation, 3(3), 127-133.

Retnawati, H., Djidu, H., Kartianom, Apino, E., \& Anazifa, R. D. (2018). Teachers' knowledge about higherorder thinking skills and its learning strategy. Problems of Education in the 21st Century, 76(2), 215230.

Saido, G. M., Siraj, S., Bakar, A., Nordin, B., Saadallah, O., Nhwhudpsl, X. P., \& Orrp, G. E. (2015). Higher Order Thinking Skills among Secondary School Students in Science Learning. Malaysian Online Journal of Educational Sciences, 3(3), 13-20.

Sani, R. (2019). Pembelajaran Berbasis HOT (Higher Order Thinking Skill). Tanggerang: Tira Smart

Schulz, H., \& FitzPatrick, B. (2016). Teachers' understandings of critical and higher order thinking and what this means for their teaching and assessments. Alberta Journal of Educational Research, 62(1), 61-86.

Setiawati, Wiwik., Asmira., A. (2019). Penilaian Berorientasi Hinger Order Thinking Skill. Direktorat Jendral Guru dan Tenaga Kependidikan Kementrian Pendidikan dan Kebudayaan.

Setiawati, S. (2019). Analisis Higher Order Thinking Skills (HOTS) Siswa Sekolah Dasar dalam Menyelesaikan Soal Bahasa Indonesia. Prosiding Seminar Nasional Pendidikan KALUNI, 2(2010), 552-557. https://doi.org/10.30998/prokaluni.v2i0.143

Suarjana, I. M., Nanci Riastini, N. P., \& Yudha Pustika, I. G. N. (2017). Penerapan Pendekatan Kontekstual Berbantuan Media Konkret Untuk Meningkatkan Aktivitas Dan Hasil Belajar. International Journal of Elementary Education, 1(2), 103-114. https://doi.org/10.23887/ijee.v1i2.11601

Sulianto, Joko., Cintang., A. (2018). Higher Order Thinking Skills (Hots) Siswa Pada Mata Pelajaran Matematika Di Sekolah Dasar Pilot Project Kurikulum 2013 Di Kota Semarang. Journal of Chemical Information and Modeling, 53(9), 1689-1699. https://doi.org/10.1017/CB09781107415324.004

Surata, I. W. (2018). Penilaian Berorientasi Keterampilan Berpikir Tingkat Tinggi (Hinger Order Thinking Skill). 1-10.

Tanujaya, B., Mumu, J., \& Margono, G. (2017). The Relationship between Higher Order Thinking Skills and Academic Performance of Student in Mathematics Instruction. International Education Studies, 10(11), 78-85. https://doi.org/10.5539/ies.v10n11p78

Thomas, G., \& Thorne, A. (2009). How To Increase Higher Level Thinking. Metarie, LA: Center for Development and Learning, 2009, 1-17. https://doi.org/http://www.cdl.org/resourcelibrary/articles /HOT.php?type=subject\&id=18

Wahyuni, Yusri., F. (2018). Higher Order Thinking Skill Instrument Design Of Student Based On Bloom 's 
Taxonomy. American Journal of Engineering Research, 7(8), 84-87.

Warrens, M. J. (2015). Five Ways to Look at Cohen Kappa. Journal of Psychology \& Psychotherapy, 05(04), 8-11. https://doi.org/10.4172/2161-0487.1000197

Wicasari, B., \& Ernaningsih, Z. (2016). Analisis Kemampuan Berpikir Siswa dalam Menyelesaikan Permasalahan Matematika yang Berorientasi pada HOTS. Prosiding Seminar Nasional Reforming Pedagogy, 249-254.

Widana, I Wayan., Adi., H. A. (2019). Modul Penyusun Soal HOTS Matematika. Direktorat Jendral Pendidikan Dasar dan Menengah.

Widana, I. W. (2017). Higher Order Thinking Skills Assessment (HOTS). Jisae: Journal of Indonesian Student Assesment and Evaluation, 3(1), 32-44. https://doi.org/10.21009/jisae.031.04

Widhiarso, W. (2011). Melibatkan Rater dalam Pengembangan Alat Ukur. 1-4.

Wilson, V. (2000). Education Forum on Teaching Skill. Executive Education Dapartement. papers://c33b182f-cf88-47e8-a9c5-ad67b5626483/Paper/p2005

Wiwin, T. T., Rudhito, M. A., Joseph, and H., \& Sriyanto. (2017). Analysis of students' higher order thinking skills in solving basic combinatorics problems. Math Didactic: Jurnal Pendidikan Matematika, 5(2), 133-147. https://doi.org/10.33654/math.v5i2.611

Yuliati, S. R., \& Lestari, I. (2018). Higher-Order Thinking Skills (Hots) Analysis of Students in Solving Hots Question in Higher Education. Perspektif Ilmu Pendidikan, 32(2), 181-188. https://doi.org/10.21009/pip.322.10

Yusuf, A. (2017). Assasmen dan Evaluasi Pendidikan. Prenadamedia Grup. 